\title{
PERFORMANCE MEASUREMENT TOOLS (PMTS) FOR GAS ENGINE GENERATOR (GEG) POWER PLANTS: A CASE STUDY AT A LEADING MEDIUM ENERGY COMPANY IN INDONESIA
}

\author{
Dedi Emawan ${ }^{1}$, Aditya Tirta Pratama2,, ${ }^{2}$, and Henry Nasution ${ }^{1}$ \\ ${ }^{1}$ Master of Mechanical Engineering, Swiss German University, Alam Sutera, Indonesia. \\ 2Department of Industrial Engineering, Swiss German University, Alam Sutera, Indonesia.
}

\begin{abstract}
Gas engine generator (GEG) power plants, as electricity producers, need to be maintained by monitoring performance and continuous improvements. The company management of power plants faces difficulties in making decisions for continuous improvements, thereby requiring performance measurement tools (PMTs) to determine the performance of a GEG power plant. The PMTs were developed using key performance indicators (KPIs) that were defined through focus group discussion (FGD) with people from different fields of expertise in the company and were based on references and the weighting of KPI criterion that was developed from the analytic hierarchy process (AHP). This study is a case study at a leading medium energy company in Indonesia. PMT is a tool to calculate performance score (PS) from the calculation of actual data, contracts, and KPI (power output/PO, heat rate/HR, operation ratio/OR, capacity factor/CF) weighting. A case study was conducted on three power plants that have different capacities and numbers of engines. The highest total performance score (TPS) value will be calculated to find the performance benchmark (PB) for each power plant. The contribution of this study is that it overcomes the problem of a limited number of references that can be used to measure performance in the energy industry.
\end{abstract}

ARTICLE HISTORY

Received: 5-3-2021

Revised: $12-7-2021$

Accepted: 25-8-2021

KEYWORDS

Power Plants,

Gas Engine Generator, Performance Indicators, Performance Measurement, Performance Score

\section{INTRODUCTION}

Electricity has become a basic requirement of every modern human being. The demand for electricity continues to increase over time. Power plants serve as electricity producers. Generally, there are 5 types of power plants in Indonesia, based on their energy sources: hydropower plant, steam (coal-fired) power plant, gas-fired power plant, diesel-fired power plant, and other renewable resources, such as solar, wind, geothermal, and biomass (Deloitte, 2016).

The total power generation capacity in Indonesia in 2018 is $63.1 \mathrm{GW}$ with various types of power plants. In terms of capacity, the most prominent power plant is the coal power plant, followed by combined cycle power plant in second place, diesel engine power plant in third place, hydropower plant in fourth, gas power plant in fifth, and gas engine power plant places last (Ministry of Energy and Mineral Resources, 2018). The development of Fuel Mix for Power Generation in 2017 shows that the use of coal for fuel places first in rank (57.22\%), followed by fuel gas (24.82\%), hydropower (7.06\%), oil (5.81\%), and finally geothermal and new and renewable energy (5.09\%) (PWC, 2018). Fuel gas (24.82\%) is the second widely used means for power generation in Indonesia. Gas turbine power plant and gas engine generator power plant are two gas-fired power plants that use fuel gas. This study focuses on a gas engine generator (GEG) power plant that uses a gas engine as its prime mover to generate electricity.

One of the GEG power plant companies is a leading medium energy company in Indonesia that developed and operated around fourteen small- and medium-size GEG power plants at ten locations in Indonesia. The company management of GEG power plant signed a contract or agreement with the National Electricity Provider as the customer. There are points in the contract where the customer imposes a penalty if the actual value does not match with the value in the contract. The actual values are the value of key performance indicators (KPIs) in the GEG power plants. Some previous studies relevant to KPI were about the KPIs of smart grid, coal-fired power plants, renewable energy, etc. However, studies about KPIs, especially for GEG power plants are still scarce. KPIs are defined through focus group discussions (FGDs) with people from different fields of expertise in the company and are based on references from Oprea and Bara (2017), Tallapragada et al. (2009), and Widhiatmaka et.al. (2017). The results of the FGD determine the KPIs used to measure performance on gas engine power plants, which are: power output $-\mathrm{PO}(\mathrm{MW})$, heat rate $-\mathrm{HR}(\mathrm{Btu} / \mathrm{kWh})$, operating ratio - OR (\%), and capacity factor - CF (\%). The weighting of those KPIs can be obtained by adopting the analytic hierarchy process (AHP).

The company has a system called Asset Management System (AMS), a web-based monitoring system developed with SQL, and the data is updated online. One of the important features of AMS is to monitor the indicator of power plants remotely. This system shows reports of production, maintenance schedule, downtime, etc. The indicators in AMS are not 
complete if used as a performance measurement tool for the GEG power plant. Therefore, a performance measurement tool (PMT) for GEG power plants is proposed. The company needs PMT because there are quite a lot of power plants owned. A PMT for GEG power plants is crucial and can help to determine the performance of a power plant, especially GEG. Power plant companies are greatly helped by PMT in making decisions for continuous improvements.

\section{LITERATURE REVIEW}

\section{Power Plant}

A power plant is an industrial facility that generates electricity from primary energy. Most power plants use one or more generators. This generator converts mechanical energy from the primary mover (rotating machine) into electrical energy in order to supply power to the electrical grid for society's electrical needs (Energy Education, 2020). A power plant is also referred to as a power station and, sometimes, a power generation station or plant.

The type of primary fuel or primary energy flow that provides a power plant its primary energy varies. The most common fuels are coal, natural gas, and uranium (nuclear power) (Energy Education, 2020).

\section{Gas Engine Generator (GEG)}

The primary mover that will be discussed here is a gas engine. A gas engine is an internal combustion engine that runs on gaseous fuel, such as natural gas, biogas, landfill gas, coal mine gas, and sewage gas. A gas engine is also called a gaseous fuel engine, or natural gas engine, or spark-ignited engine. The company uses GEG with a GE brand of Jenbacher. Jenbacher GEs are manufactured in Jenbach, Austria, which has more than five decades of experience in gas engine manufacturing and has more than 10,000 gensets installed worldwide so far (GE Jenbacher, 2013). A case study was conducted in a company that has numerous GEG power plants. The company has a GE fleet of Jenbacher GEG set for supporting the business. The total units of GEG set are 201 units. The capacity of each gas engine is different. The GE Jenbacher type 320 has a generator output of $1,067 \mathrm{~kW}$ of electricity at $50 \mathrm{~Hz} 400 \mathrm{~V}$. The Jenbacher GE type $620 \mathrm{has}$ a generator output of $3,349 \mathrm{~kW}$ of electricity at $50 \mathrm{~Hz} 11 \mathrm{kV}$. The Jenbacher GE type 624 has a generator output of 4,029 $\mathrm{kW}$ of electricity at $50 \mathrm{~Hz} 11 \mathrm{kV}$ (GE Jenbacher, 2013).

\section{Performance Measurement System (PMS)}

Performance measurement is the process of collecting, analyzing, and/or reporting information regarding the performance of an individual, group, organization, system, or component (Behn, 2003). Performance measurement is integral to performance management and provides a basis for performance improvement programs (Kuragu et al., 2016).

In order for companies to increase their competitiveness, a performance measurement system (PMS) is needed, which is a system that provides relevant information for efficiency and effective management in making measurable decisions (Chalmeta et al., 2012). PMS is dynamic in nature, integrated with measurements and evaluations of the efficiency and effectiveness of business operations, which can be used as a basis for making decisions to increase competitiveness in a company.

The application of performance measurement systems (PMS) are used in the construction industries in the United Kingdom, the United States of America, and Denmark (using performance measurement tools Project Scorecard/ProScor and Contractor Scorecard/ConScor) (Kuragu et al., 2016).

Performance measurement is necessary for companies because it is useful for achieving 8 specific managerial purposes namely: evaluate, control, budget, motivate, promote, celebrate, learn, and improve (Behn, 2003). To achieve these goals, it is necessary to:

- $\quad$ Evaluate - requires multiple measures, compared with multiple standards

- Control - requires a mechanism of control

- $\quad$ Budget - requires a description of the efficiency of various activities

- Motivate - requires almost real-time measurements of outputs to compare with production targets

- $\quad$ Promote - requires aspects of performance about how many citizens personally care

- Celebrate - requires periodic and significant performance targets when achieved, provides people with a real sense of personal and collective accomplishment

- $\quad$ Learn - requires a large number and wide variety of measures

- Improve - requires an understanding of how they can influence the behavior of the people whose actions affect the outputs and outcomes they seek

Wongrassamee et al. (2003) took the improvement approach of Kaplan and Norton's (1996) Balanced Scorecard and the EFQM Excellence Model for performance measurement frameworks in companies. The EFQM (European Foundation for Quality Management) Excellence Model demonstrates excellence in the management of quality fundamental to continuous improvement. This model provides a systematic perspective for understanding performance management. The Excellence Model is a non-prescriptive framework that is based on nine criteria (Leadership, People Management, Policy and Strategy, Resources, Process, People Satisfaction, Customer Satisfaction, Impact on Society, Business Results). The Balanced Scorecard is a comprehensive framework in which an organization's mission and strategic objectives can be 
translated into a set of performance measures (Kaplan and Norton, 1996). The purpose of this Balance Scorecard framework is to provide a comprehensive overview of the business and focus on critical areas, implementing a future strategy for the organization. The Balanced Scorecard framework includes 4 main perspectives namely: Financial, Customer, Internal Business Process, and Learning \& Growth. In this Balanced Scorecard framework, there is a strategy map created generically to show any measurement strategy at each perspective (Wongrassamee et al., 2003). PMT is part of the Learning \& Growth Perspective - Information Capital Section - Planning, Monitoring, Reporting.

A Balanced Scorecard is a method widely used to measure performance in companies. In the first generation, the BSC is a system for evaluating performance with major constituent elements (Morisawa, 2002), such as:

- $\quad$ Performance measures

- Breakdown of strategy

- $\quad$ Four perspectives

- $\quad$ Strategic objective, performance indicators, leading indicators, KPI

- $\quad$ Performance linked compensation

Kanzai Electric Power Co., Ltd., the second-largest electric power company in Japan, used BSC for measuring performance by applying the performance-linked contract since 1999 (Morisawa, 2002). This contract is based on strategic objectives and performance indicators that have been set as standardized indicators. In this study, the performance measurement approach uses performance indicators that are determined as KPI through an FGD with people from different fields of expertise inside the company.

\section{Key Performance Indicators (KPI)}

A performance indicator or key performance indicator (KPI) is a type of performance measurement. KPI is a measuring tool that describes the effectiveness of a company in achieving its business goals. Companies use KPIs to measure the success of achieving their targets (Chalmeta et al., 2012). KPI is for monitoring and detecting low performance in power plant operation, investigating issues, and setting up maintenance plans in order to minimize the operational cost (Oprea \& Bara, 2017). Referring to Tallapragada et al. (2009), there are three categories of KPI: Technical, Commercial, Technical, and Operational Capabilities. In this study, the used performance indicators are only technical performance indicators in gas engine power plants.

Technical performance indicators are KPIs in which the indicators used are only for the technical parts. In this study, the technical performance indicators are a combination of information from the available literature. Oprea and Bara (2017) mentioned that technical performance indicators are based on operational data, consisting of:

1. The average power $\left(\mathrm{P}_{\mathrm{Avg}}\right)$, the ratio between produced energy $(\mathrm{W})$ and runtime $(\mathrm{t})$

2. Installed power load factor $\left(\mathrm{K}_{\mathrm{u}}\right)$, the ratio of average power $\left(\mathrm{P}_{\mathrm{avg}}\right)$, and install power $\left(\mathrm{P}_{\mathrm{i}}\right)$

3. Installed power load duration $\left(\mathrm{T}_{\mathrm{i}}\right)$, based on installed power load factor $\left(\mathrm{K}_{\mathrm{u}}\right)$ multiply by runtime $(\mathrm{t})$

4. Maximum power load duration $\left(\mathrm{T}_{\max }\right)$, the ratio between generated energy $\left(\mathrm{W}_{\mathrm{a}}\right)$ and maximum output $\left(\mathrm{P}_{\max }\right)$

5. Power factor $(\cos \theta)$, determined based on active energy $\left(\mathrm{W}_{\mathrm{a}}\right)$ and reactive energy $\left(\mathrm{W}_{\mathrm{r}}\right)$

6. Performance index (PI), the ratio between generated power/energy and forecasted power/energy

The operational technical performance indicators above are applied on most power plants, including on wind power plants and photovoltaic power plants.

Meanwhile, according to Tallapragada et al. (2009), technical performance indicators consist of:

1. Capacity factor is the ratio of actual generation power to maximum capacity to generate

2. Load factor is the ratio of average annual load to maximum annual load

3. Operating ratio is the ratio of operating to installed capacity

The technical performance indicators above are applied to power plants that use coal-fire, gas-fire, hydropower, nuclear, oil-fire, and renewables.

According to Widhiatmaka et al. (2017), technical performance indicators for a coal power plant with a low heat rate indicator will produce maximum efficiency for the power plant. The heat rate is the ratio of energy used to generate 1 $\mathrm{kWh}$ of electricity.

KPIs that are used to measure performance on gas engine power plants refer to Oprea and Bara (2017), Tallapragada et al. (2009), and Widhiatmaka et al. (2017) involving:

1. The average power $\left(\mathrm{P}_{\mathrm{Avg}}\right)$, the ratio between produced energy $(\mathrm{W})$ and runtime $(\mathrm{t})$

2. Installed power load factor $\left(\mathrm{K}_{\mathrm{u}}\right)$, the ratio of average power $\left(\mathrm{P}_{\mathrm{avg}}\right)$, and install power $\left(\mathrm{P}_{\mathrm{i}}\right)$

3. Power factor $(\operatorname{Cos} \theta)$, determined based on active energy $\left(\mathrm{W}_{\mathrm{a}}\right)$ and reactive energy $\left(\mathrm{W}_{\mathrm{r}}\right)$

4. Capacity factor, the ratio of actual generation power to maximum capacity to generate

5. Operating ratio, the ratio of operating to installed capacity

6. The heat rate, the ratio of energy used to generate $1 \mathrm{kWh}$ of electricity

\section{Analytic Hierarchy Program (AHP)}

The Analytic Hierarchy Process (AHP), introduced by Thomas Saaty, is an effective tool for dealing with complex decision-making and may aid the decision-makers to set priorities and make the best decision. By reducing complex decisions to a series of pairwise comparisons, and then synthesizing the results, the AHP helps to capture both subjective 
and objective aspects of a decision. In addition, the AHP incorporates a useful technique for checking the consistency of the decision maker's evaluations, thus reducing the bias in the decision-making process (Saaty, 1988).

The hierarchy structure in AHP is divided into three levels. Level 0 is the goal of the analysis. Level 1 is factors or criteria that are related to the alternatives to reach the goal. The criteria are ordered from the highest priorities on the left to the lower priorities on the right. Lastly, level 2 is the alternative choices, which is the group of options. The lines between levels indicate the relationship between goal, criteria, and alternatives (Saaty, 1988).

Based on Saaty's (1988) opinion, the AHP considers a set of evaluation criteria and a set of alternative options from which the best decision is to be made. It is important to note that, since some of the criteria could be contrasting, it is not true in general that the best option is the one that optimizes every single criterion, rather the one that achieves the most suitable trade-off among the different criteria.

The AHP generates a weight for each evaluation criterion according to the decision maker's pairwise comparisons of the criteria. The higher the weight, the more important the corresponding criterion. Next, for a fixed criterion, the AHP assigns a score to each option according to the decision maker's pairwise comparisons of the options based on that criterion. The higher the score, the better the performance of the option with respect to the considered criterion. Finally, the AHP combines the criteria weights and the options scores, thus determining a global score for each option, and a consequent ranking. The global score for a given option is a weighted sum of the scores it obtained with respect to all the criteria (Saaty, 1988).

Referring to Yang et al. (2010), the AHP has been used to weight the identified indicators for assessing the energy efficiency of residential buildings in the hot summer and cold winter in China. The AHP method was adopted in order to rank assessment themes and identify the priorities. The outcome is the Malaysian Refurbishment Assessment Scheme (MRAS) (Kamaruzzaman et al., 2018). The AHP methodology is used to evaluate knowledge management (KM) performance by comparing and ranking each division to find the division in Oil and Gas company that represents the most desirable performance to the least desirable performance (Ruvania et al., 2015).

\section{Gas Engine Generator (GEG) Power Plants}

This study used the three GEG power plants owned by the company. The total power plants owned by the company are fourteen power plants in ten locations in Indonesia (Internal Company Data, 2020). The reason for only using the three GEG power plants for this study is that the three power plants have different installed capacities and the engines are also stationed in different locations in Indonesia. The three GEG power plants can be described as follows:

1. Power Plant A $\rightarrow$ Installed capacity: $46.89 \mathrm{MW}$; number of engines: 15 units; located in Sumatera Island

2. Power Plant B $\rightarrow$ Installed capacity: $25.57 \mathrm{MW}$; number of engines: 8 units; located in Sumatera Island

3. Power Plant $\mathrm{C} \rightarrow$ Installed capacity: 6.70 MW; number of engines: 2 units; located in Kalimantan Island

\section{METHODOLOGY}

Performance measurement tools (PMTs) are for determining the performance of a GEG power plant. In this study, the PMT was developed using key performance indicators (KPI) that were determined through forum group discussion (FGD) involving people from different fields of expertise in the company and were based on references and the weighting of each KPI criterion that was developed by the analytic hierarchy process (AHP). This study was a case study at a leading medium energy company in Indonesia. PMT is a tool to calculate the performance score (PS) from the calculation of the actual data, contracts, and KPI (power output/PO, heat hate/HR, operation ratio/OR, capacity factor/CF) weighting. If there is a gap in the PS, then it can indicate a penalty from the customer, especially PO and HR. The research methodology for developing PMT is shown in Figure 1.

Defining the performance indicators based on literature review and FGD with people from different fields of expertise in a company is the first step. The next step is using the AHP method by preparing the AHP structure and the pairwise comparison matrix. Those are the reference for developing the questionnaire. This questionnaire will be distributed to the people in the company. The reason for using AHP is that AHP provides a systematic approach for weighting performance criteria to provide a comprehensive performance measure. In AHP, the problem analysis is set in a hierarchy that consists of goals, criteria, and alternatives. The hierarchy indicates a relationship between elements of one level with those of the level immediately below. Fig. 2 shows the hierarchy or AHP structure. After the hierarchy has been constructed, an analysis will be conducted using pairwise comparisons that derive numerical scales of measurement. Table 1 shows the pairwise comparisons. The pairwise comparisons of criteria generated were organized into a square matrix. After the matrix is set, the next process is synthesization. Synthesization is the process of calculating the priority of each criterion in terms of its contribution to the overall goal of achieving GEG power plant performance. Then, priorities are established, which represent the weights of each alternative. The higher the weight, the higher the KPI. 


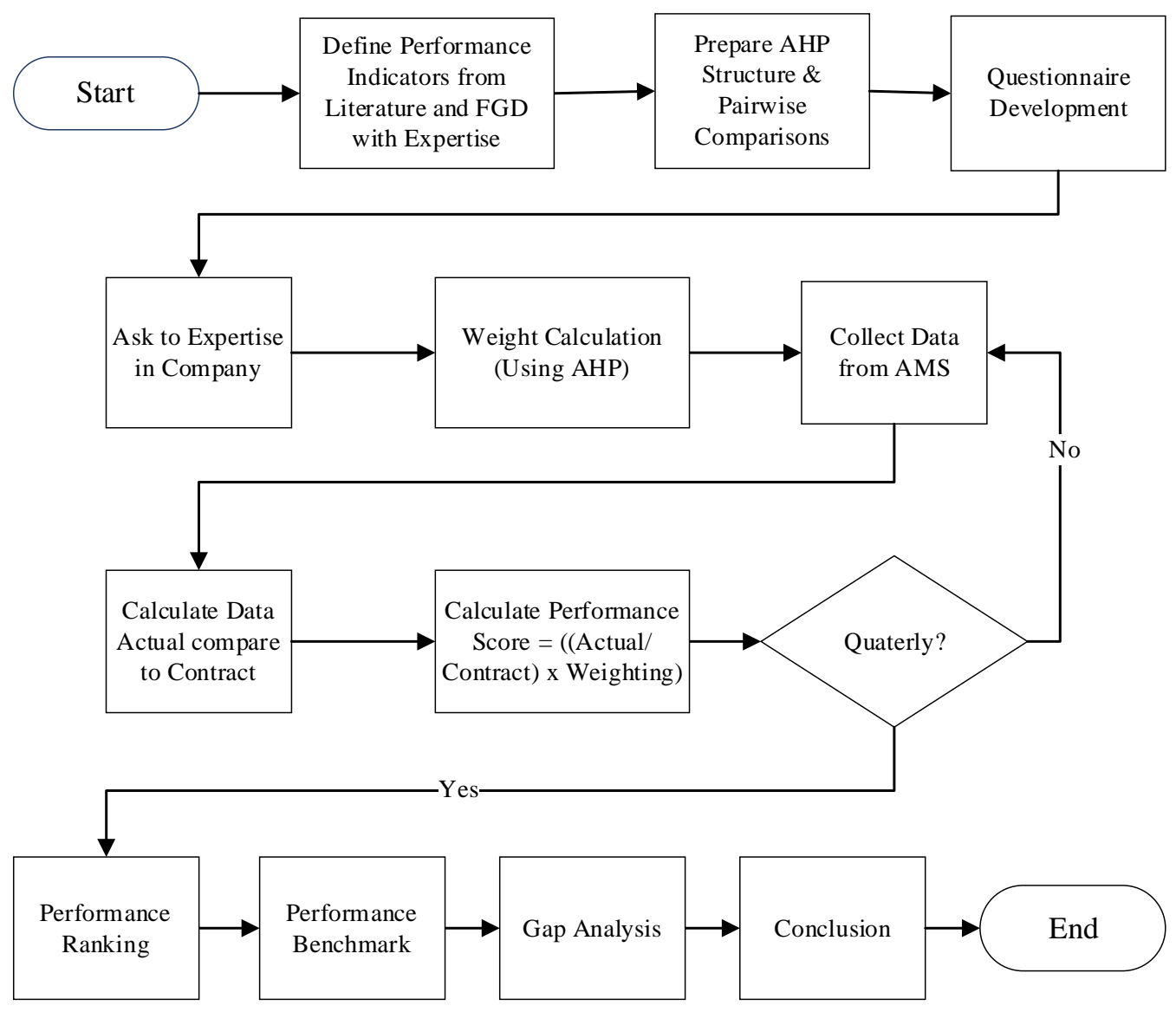

Figure 1. Research Methodology

Figure 2 shows the AHP structure used in this study. At level 0, the intended goal is the key performance indicators used in the gas engine power plant. For the level 1 criteria, the weighting involves power output $(\mathrm{kW})$, heat rate $(\mathrm{Btu} / \mathrm{kWh})$, operating ratio $(\%)$, and capacity factor $(\%)$. Meanwhile, level 2 alternatives are using data from Power Plant A, Power Plant B, and Power Plant C

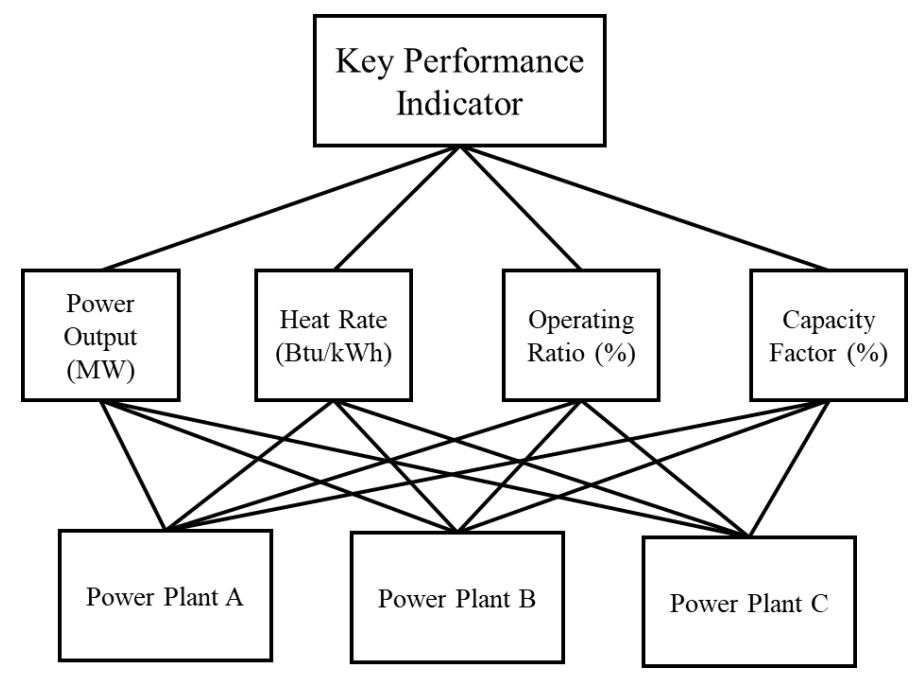

Figure 2. AHP Structure

The AHP pairwise comparison matrix of this study can be seen in Table 1. 
Table 1. Research Pairwise Comparisons

\begin{tabular}{ccccc}
\hline Criteria & Power Output & Heat Rate & $\begin{array}{c}\text { Operating } \\
\text { Ratio }\end{array}$ & $\begin{array}{c}\text { Capacity } \\
\text { Factor }\end{array}$ \\
\hline Power Output & 1 & & & \\
Heat Rate & & 1 & & \\
Operating Ratio & & 1 & 1 \\
Capacity Factor & & & \\
\hline
\end{tabular}

The data used was taken from the existing Asset Management System (AMS). The data used are data from 3 power plants: Power Plant A, Power Plant B, and Power Plant C. These three power plants have different installed capacities and engines. Besides, the reference to the contract value of each power plant was also taken from the contract documents owned by the company. Table 2 shows the information from these three power plants.

Table 2. Contract Information each Power Plant

\begin{tabular}{cccccccc}
\hline & & & & \multicolumn{4}{c}{ Contract } \\
\cline { 5 - 8 } No & Plant Name & $\begin{array}{c}\text { Installed } \\
\text { Capacity } \\
(\mathrm{Mw})\end{array}$ & $\begin{array}{c}\text { Engine } \\
\text { Number }\end{array}$ & $\begin{array}{c}\text { Capacity } \\
(\mathrm{Mw})\end{array}$ & $\begin{array}{c}\text { Heat Rate } \\
(\text { Btu/Kwh) }\end{array}$ & $\begin{array}{c}\text { Capacity } \\
\text { Factor }(\%)\end{array}$ & $\begin{array}{c}\text { Operating } \\
\text { Ratio }(\%)\end{array}$ \\
\hline 1 & Power Plant A & 46.89 & 15 & 30 & 9,270 & 40 & 63.98 \\
2 & Power Plant B & 25.57 & 8 & 15 & 10,112 & 80 & 58.66 \\
3 & Power Plant C & 6.70 & 2 & 3 & 10,000 & 80 & 44.78 \\
\hline
\end{tabular}

A penalty will be applied when the actual value capacity power output indicator (MW) is less than the contract value and the actual heat rate value $(\mathrm{Btu} / \mathrm{kWh})$ indicator is higher than the contract value.

Data taken from the AMS is the actual data for each power plant. This actual data will be compared with the contract data so that the actual / contract ratio will be obtained. This calculation is performed monthly on the criteria for average power output $(\mathrm{MW})$, heat rate $(\mathrm{Btu} / \mathrm{kWh})$, operation ratio (\%), capacity factor (\%) at Power Plant A, Power Plant B, and Power Plant C.

The performance score (PS) is obtained using Equation 1:

$$
\text { Performance Score }=\left(\left(\frac{\text { Actual }}{\text { Contract }}\right) \times \text { Weighting }\right)
$$

The calculation of the performance score (PS) is carried out monthly on the criteria for average power output (MW), heat rate $(\mathrm{Btu} / \mathrm{kWh})$, operation ratio (\%), capacity factor $(\%)$ at Power Plant A, Power Plant B, and Power Plant C. Each criterion will have a performance score in the form of a ratio. All performance scores on the criteria are added together to get a total performance score (TPS).

After the TPS is obtained, the next step is to analyze the results of calculations that have been carried out with the aim of getting performance rankings and performance benchmarks for each power plant within 1 year. Furthermore, a gap analysis is carried out for each of these power plants.

A gap analysis was conducted by comparing the difference between the actual PS value based on the KPI criteria and the standard PS value based on the KPI criteria. The result of the gap analysis was used to find an area to be concerned. From the gap, the company can determine — based on the performance of the power plants — whether or not they will receive a penalty from the customer and undertake the necessary actions for continuous improvement resulting in a better performance in the future.

The last step is the conclusion on any process for improvements based on the summary finding. The result of the gap analysis of each power plant difference was carefully determined whether there is any benefit obtained by incorporating other processes or portions of the other process that will be suggested as improvement recommendations. The gap analysis was conducted by comparing the expectation of PS, which is at least as same as with the other power plant with the highest weight of PS. 


\section{FINDINGS AND DISCUSSIONS}

The KPIs were used by the company and serve as an indicator for calculating its performance to reflect the performance of the GEG power plant. The KPIs used to measure performance on gas engine power plants were:

1. Power output (MW) - PO is the total power output average produced by a power plant

2. Heat rate $(\mathrm{Btu} / \mathrm{kWh})-\mathrm{HR}$ is the amount of energy used by a power plant to generate one kilowatt-hour $(\mathrm{kWh})$ of energy. Energy is in British thermal units (BTU).

3. Operating ratio $(\%)-\mathrm{OR}$ is the ratio of gas engine operating to the total gas engine installed in a power plant. The equation for the operating ratio is

$$
\text { Operating ratio }=\frac{\text { operating GEG }(\text { Units })}{\text { Installed GEG (Units) }} \times 100 \%
$$

4. Capacity factor $(\%)-\mathrm{CF}$ is the ratio of actual generation of power to the maximum capacity to generate. This indicator measures the percentage of installed capacity that is utilized. The equation for capacity factor is

$$
\text { Capacity factor }=\frac{\text { Electricity Generated }(M W)}{\text { Installed Capacity }(M W)} \times 100 \%
$$

The data is collected from the company's existing system, the AMS. The relationship between AMS as an existing system and PMT can be seen in Figure 3.

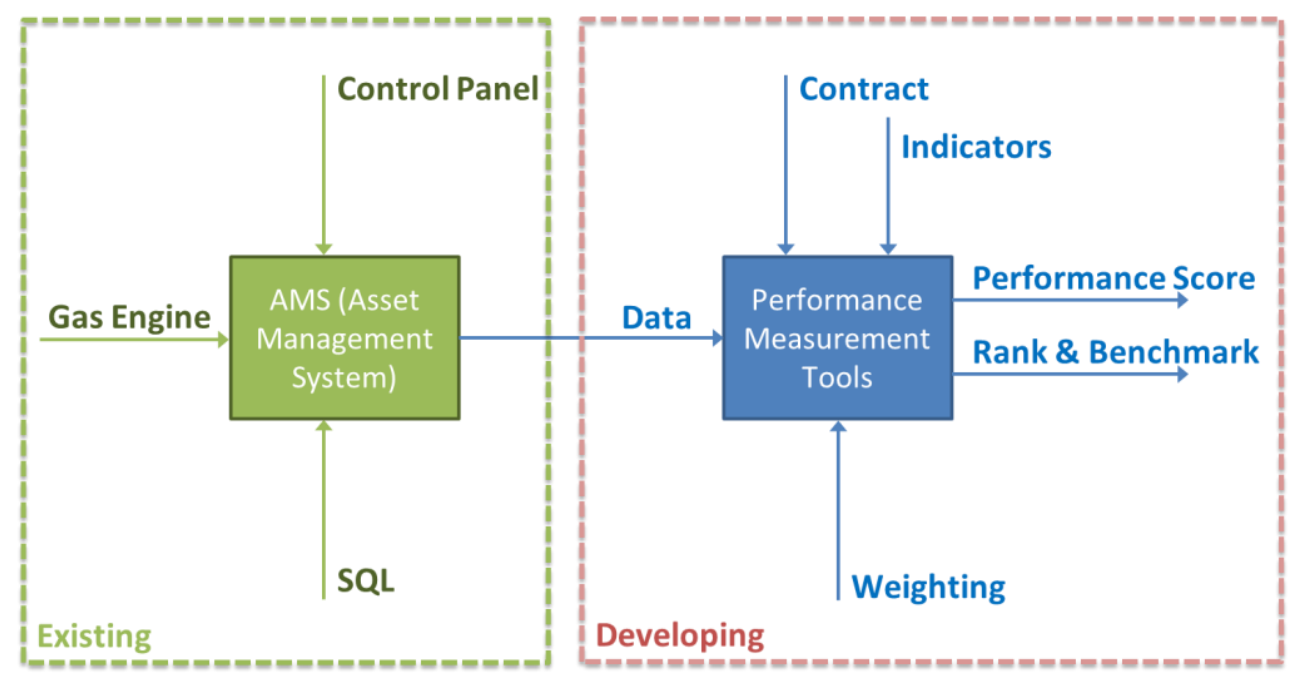

Figure 3. Performance Measurement Tools - IDEF0

Figure 3 is a notation for the IDEF0 modeling system (introduced by NASA) for developing the PMT. AMS, as an existing system from the company, provides data for a monitoring system in which the data is obtained from the gas engine generators in each power plant, which is controlled by the gas engine generator control panel located in the panel room in the power plant. The mechanism of AMS uses SQL to make it easier to arrange and store the data on a server owned by the company. AMS can be accessed anywhere because it is web-based. The data from the AMS will be processed by the PMT (developing system) to obtain the performance score (PS), performance rank (PR), and performance benchmark $(\mathrm{PB})$ for each power plant. The performance score can be calculated after obtaining the weighting value for each KPI.

The calculation of the weight for each criterion is derived from the aggregate of the relative weights of criteria from the AHP calculation result. The aggregation procedure was based on geometric means, which is the square root of 4 (number of criteria) from the multiplication of each weighting of expertise. After obtaining the geometric mean value, the normalized geometric means were then calculated by dividing the geometric mean value of each criterion by the total number of the geometric mean. Afterward, the next step calculates it into a normalized geometric mean for each criterion. Table 3 shows the results obtained from calculating the weight of each criterion. These will be used as a reference for the next calculation, and the ranking is: 1 . Power output/PO (MW) $-(70.81 \%) ; 2$. Heat rate/ HR (Btu/kWh) $-(14.91 \%) ; 3$. Operating ratio/OR $(\%)-(8.06 \%)$; and 4. Capacity factor/CF $(\%)-(6.22 \%)$. 
Table 3. The Weight of Each Criterion

\begin{tabular}{rlccc}
\hline No & Criteria & Code & Weights & Rank \\
\hline 1 & Power output (MW) & PO & $70.81 \%$ & 1 \\
2 & Heat rate (Btu/kWh) & HR & $14.91 \%$ & 2 \\
3 & Operating ratio (\%) & OR & $8.06 \%$ & 3 \\
4 & Capacity factor (\%) & CF & $6.22 \%$ & 4 \\
\hline & & Total & $100.00 \%$ \\
\end{tabular}

The penalty from the customer will be applied when the actual capacity indicator value (power output - MW) is less than the contract value and the actual heat rate value $(\mathrm{Btu} / \mathrm{kWh})$ indicator is higher than the contract value.

The performance score (PS) is calculated in the next step after obtaining all of the ratios between the actual and contract for all criteria for each power plant throughout 1 year. PS is the multiplication of the actual/contract value with the weighting. The weighting value used was based on Table 3. The calculation of the PS was carried out monthly on the criteria for power output average (MW), heat rate (Btu/kWh), operation ratio (\%), and capacity factor (\%) at Power Plant A, Power Plant B, and Power Plant C. Each criterion will have a PS in the form of a ratio. All PS scores in the criteria were added together to get the total performance score (TPS). The result of the calculation of the PS and ranking can be seen in Table 4-6 for Power Plant A, Power Plant B, and Power Plant C.

Table 4. Performance Score and Rank Result of Power Plant A in 2019

\begin{tabular}{|c|c|c|c|c|c|c|c|}
\hline \multirow{2}{*}{ No } & \multirow{2}{*}{ Month } & \multicolumn{5}{|c|}{ Performance Score } & \multirow{2}{*}{ Rank } \\
\hline & & $\mathrm{PO}$ & HR & OR & $\mathrm{CF}$ & Total & \\
\hline 1 & January & 0.33 & 0.16 & 0.05 & 0.05 & 0.59 & 12 \\
\hline 2 & February & 0.33 & 0.16 & 0.06 & 0.05 & 0.60 & 11 \\
\hline 3 & March & 0.43 & 0.16 & 0.08 & 0.06 & 0.72 & 10 \\
\hline 4 & April & 0.46 & 0.16 & 0.08 & 0.06 & 0.76 & 9 \\
\hline 5 & May & 0.59 & 0.16 & 0.08 & 0.08 & 0.92 & 1 \\
\hline 6 & June & 0.56 & 0.16 & 0.09 & 0.08 & 0.90 & 2 \\
\hline 7 & July & 0.51 & 0.16 & 0.08 & 0.07 & 0.82 & 6 \\
\hline 8 & August & 0.50 & 0.16 & 0.09 & 0.07 & 0.82 & 5 \\
\hline 9 & September & 0.48 & 0.16 & 0.08 & 0.07 & 0.79 & 8 \\
\hline 10 & October & 0.49 & 0.16 & 0.08 & 0.07 & 0.79 & 7 \\
\hline 11 & November & 0.55 & 0.15 & 0.08 & 0.08 & 0.86 & 4 \\
\hline 12 & December & 0.56 & 0.15 & 0.08 & 0.08 & 0.88 & 3 \\
\hline
\end{tabular}

Table 4 shows the highest total performance score (Rank 1) of Power Plant A in 2019 is in May (0.92). Figure 4 shows the chart of performance score of Power Plant A in 2019. The TPS value increases from January to December. 


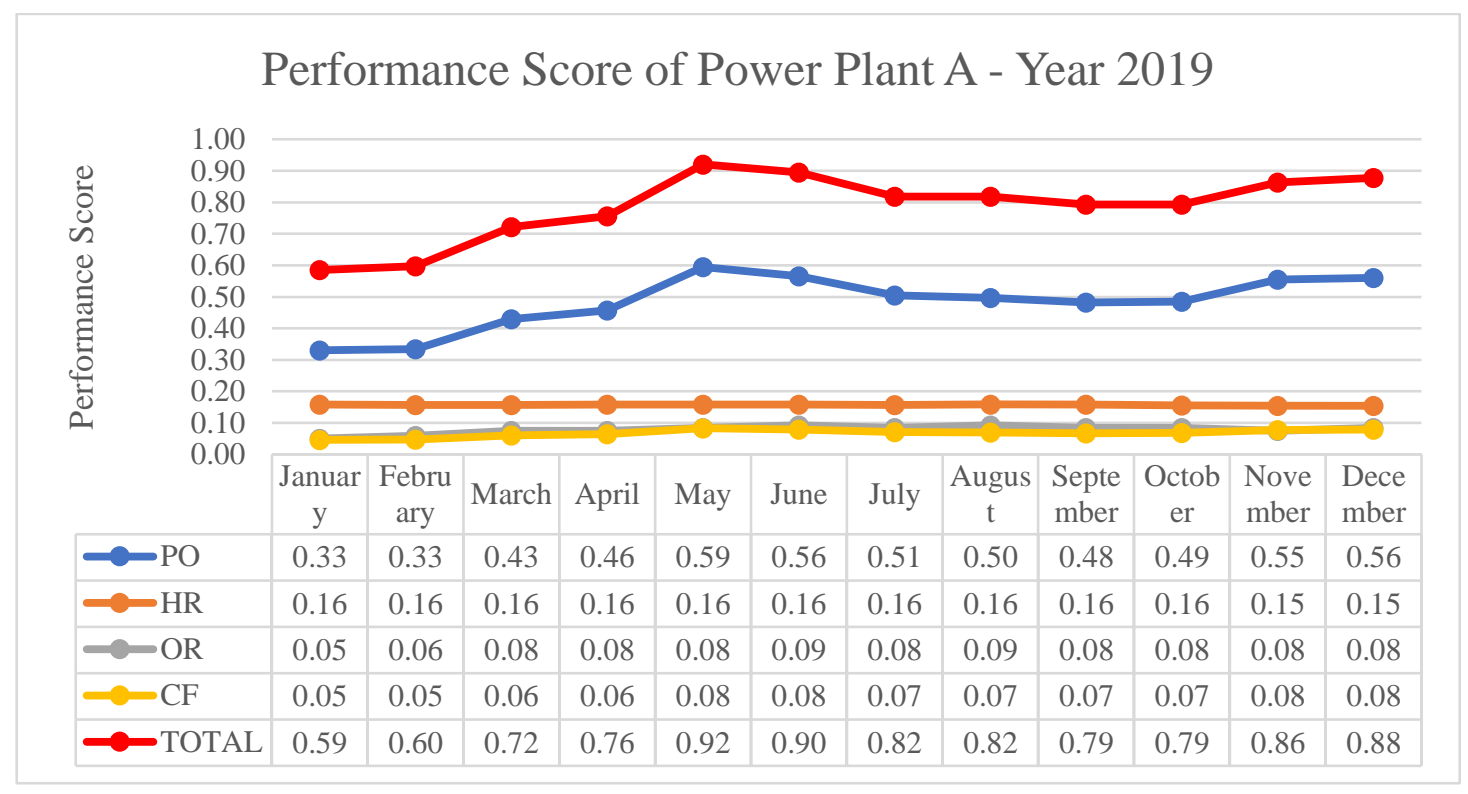

Figure 4. Performance Score Graph of Power Plant A in 2019

Table 5 shows the performance score and rank result of Power Plant B in 2019. The highest TPS (Rank 1) of Power Plant B in 2019 is in November (1.05). Figure 5 shows the chart of performance score of Power Plant B in 2019. The TPS value increases from January to April and increases again from August to December 2019.

Table 5. Performance Score and Rank Result of Power Plant B in 2019

\begin{tabular}{clcccccc}
\hline \multirow{2}{*}{ No } & \multirow{2}{*}{ Month } & \multicolumn{7}{c}{ Performance Score } & Rank \\
\cline { 3 - 6 } & & PO & HR & OR & CF & TOTAL & 11 \\
\hline 1 & January & 0.41 & 0.14 & 0.10 & 0.03 & 0.69 & 10 \\
2 & February & 0.51 & 0.15 & 0.10 & 0.03 & 0.79 & 6 \\
3 & March & 0.63 & 0.15 & 0.10 & 0.04 & 0.91 & 3 \\
4 & April & 0.68 & 0.15 & 0.10 & 0.04 & 0.97 & 5 \\
5 & May & 0.63 & 0.15 & 0.10 & 0.04 & 0.92 & 8 \\
6 & June & 0.53 & 0.15 & 0.10 & 0.03 & 0.82 & 7 \\
7 & July & 0.59 & 0.15 & 0.10 & 0.04 & 0.88 & 12 \\
8 & August & 0.38 & 0.17 & 0.10 & 0.02 & 0.68 & 9 \\
9 & September & 0.49 & 0.16 & 0.12 & 0.03 & 0.80 & 4 \\
10 & October & 0.67 & 0.15 & 0.10 & 0.04 & 0.96 & $\mathbf{1}$ \\
$\mathbf{1 1}$ & November & $\mathbf{0 . 7 4}$ & $\mathbf{0 . 1 5}$ & $\mathbf{0 . 1 2}$ & $\mathbf{0 . 0 5}$ & $\mathbf{1 . 0 5}$ & 2 \\
12 & December & 0.71 & 0.15 & 0.12 & 0.05 & 1.02 & \\
\hline
\end{tabular}




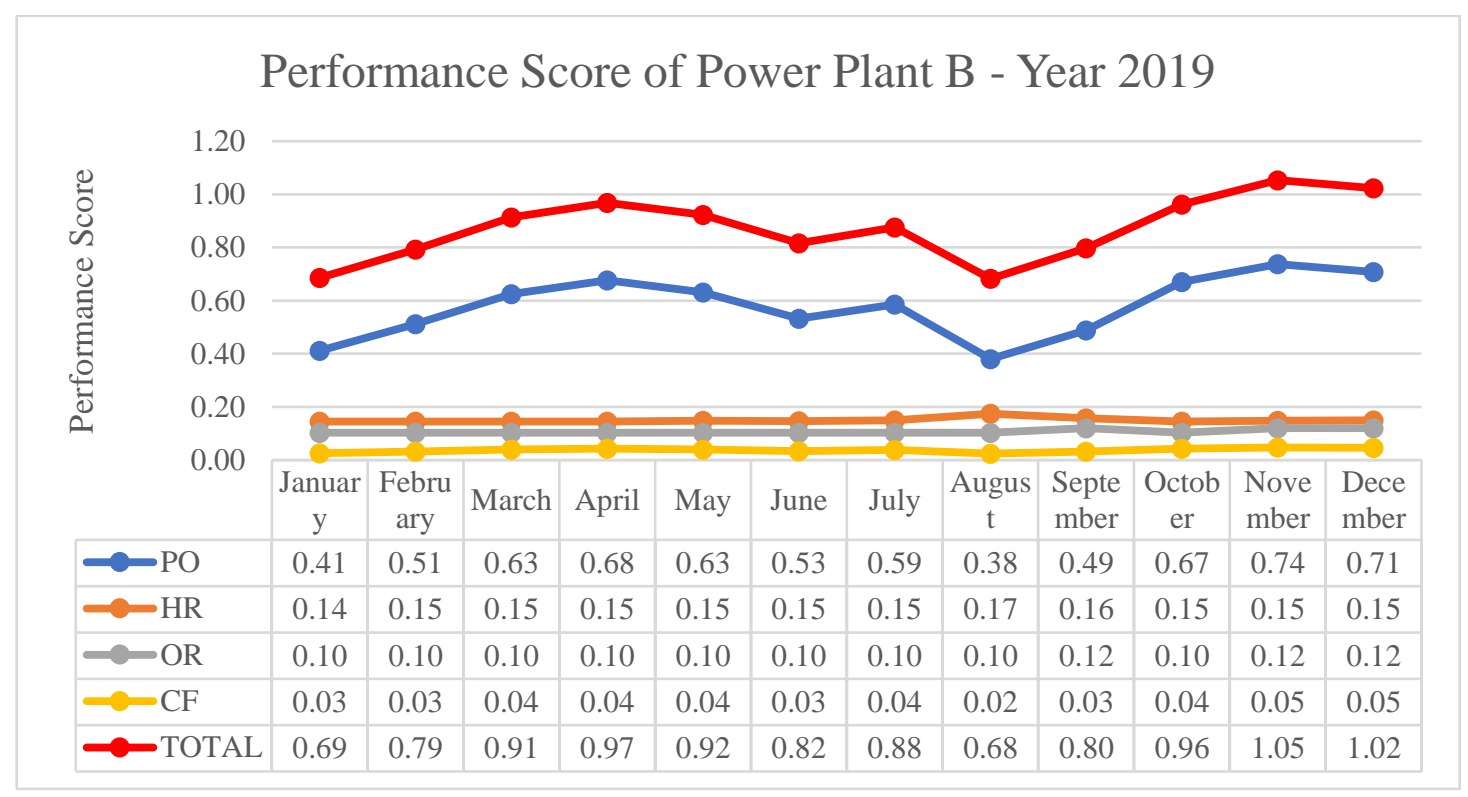

Figure 5. Performance Score Graph of Power Plant B in 2019

Table 6 shows the performance score and rank result of Power Plant C in 2019. The highest TPS (Rank 1) of Power Plant C in 2019 is in June (1.60). Figure 6 shows the chart of performance score of Power Plant C in 2019. The TPS value is almost flat from January to December 2019.

Table 6. Performance Score and Rank Result of Power Plant C in 2019

\begin{tabular}{clcccccc}
\hline \multirow{2}{*}{ No } & & \multicolumn{9}{c}{ Performance Score } & \multirow{2}{*}{ Rank } \\
\cline { 3 - 6 } & & PO & HR & OR & CF & Total & \\
\hline 1 & January & 1.10 & 0.14 & 0.18 & 0.05 & 1.47 & 10 \\
2 & February & 1.13 & 0.14 & 0.18 & 0.06 & 1.51 & 8 \\
3 & March & 1.05 & 0.14 & 0.18 & 0.05 & 1.43 & 12 \\
4 & April & 1.20 & 0.14 & 0.18 & 0.06 & 1.58 & 4 \\
5 & May & 1.21 & 0.14 & 0.18 & 0.06 & 1.59 & 2 \\
6 & June & 1.22 & $\mathbf{0 . 1 4}$ & $\mathbf{0 . 1 8}$ & $\mathbf{0 . 0 6}$ & $\mathbf{1 . 6 0}$ & $\mathbf{1}$ \\
7 & July & 1.12 & 0.14 & 0.18 & 0.06 & 1.50 & 9 \\
8 & August & 1.18 & 0.14 & 0.18 & 0.06 & 1.55 & 6 \\
9 & September & 1.19 & 0.14 & 0.18 & 0.06 & 1.57 & 5 \\
10 & October & 1.17 & 0.14 & 0.18 & 0.06 & 1.54 & 7 \\
11 & November & 1.20 & 0.14 & 0.18 & 0.06 & 1.58 & 3 \\
12 & December & 1.08 & 0.14 & 0.18 & 0.05 & 1.45 & 11 \\
\hline
\end{tabular}




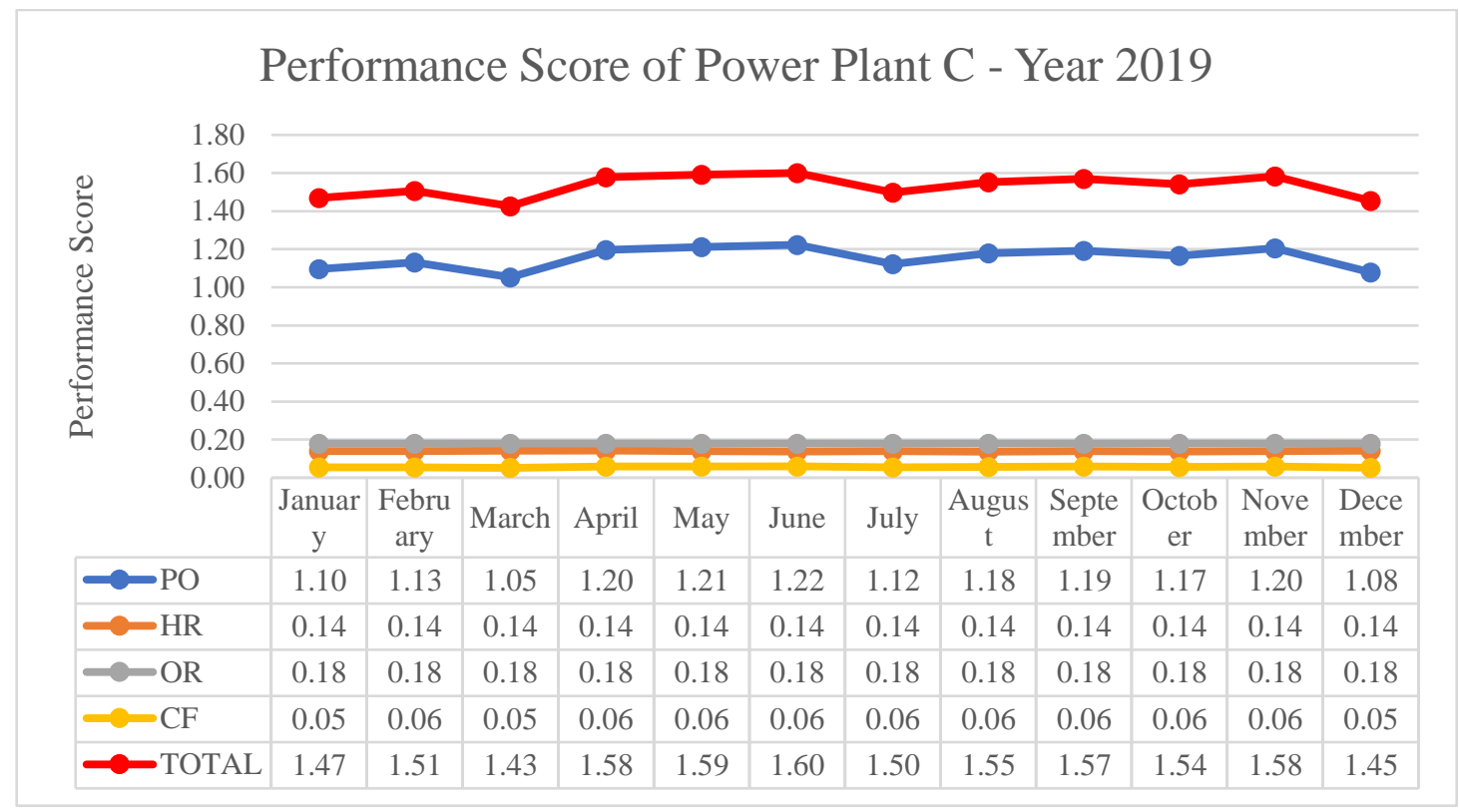

Figure 6. Performance Score Graph of Power Plant C in 2019

From the PS of the three power plants in 2019, the performance benchmark (PB) can be identified. The PB is the highest value of the total performance score (TPS) for each year. Table 7 shows the performance benchmarks of the power plants.

Table 7. Performance Benchmarks of the Power Plants

\begin{tabular}{cclccccc}
\hline \multirow{2}{*}{ Power Plant } & \multirow{2}{*}{ Year } & \multirow{2}{*}{ Month } & \multicolumn{5}{c}{ Performance Score } \\
\cline { 4 - 7 } & & & PO & HR & OR & CF & Total \\
\hline A & 2019 & May & 0.594 & 0.159 & 0.084 & 0.083 & 0.920 \\
B & 2019 & November & 0.737 & 0.149 & 0.120 & 0.047 & 1.054 \\
C & 2019 & June & 1.223 & 0.137 & 0.180 & 0.060 & 1.600 \\
\hline
\end{tabular}

Table 7 shows that the TPS (0.92) of Power Plant A in May 2019 can be used as a PB for 2019. For Power Plant B, its TPS in November 2019 (1.054) can be used as a PB for 2019. For Power Plant C, its TPS in June 2019 (1.60) can be used as a PB for 2019. Moreover, if the TPS value is greater than $100 \%$, i.e., 1.00, then the performance of the power plant is much better.

A gap analysis is conducted by comparing the difference between the criteria of KPI with low PS compared to the KPI with the standard value of KPI criteria. The result of the gap analysis was used to find the area to be concerned about. From the gap, the company can determine — based on the performance of the power plants - whether or not they will receive a penalty from the customer and undertake the necessary actions for continuous improvement and, thus, better performance in the future.

The gap in the PS can be calculated from the difference between the standard criteria and the PS of each criterion. This calculation was carried out on the PB of each power plant in 2019. Table 8 shows the results of the calculations.

Table 8. Gap Performance Score (PS) That Refers to the Performance Benchmark (PB)

\begin{tabular}{|c|c|c|c|c|c|c|c|c|c|c|c|c|c|c|}
\hline \multirow{2}{*}{$\begin{array}{c}\text { Power } \\
\text { Plant }\end{array}$} & \multirow[b]{2}{*}{ Year } & \multirow[b]{2}{*}{ Month } & \multicolumn{12}{|c|}{ Performance Score } \\
\hline & & & $\begin{array}{c}\text { STD } \\
\text { PO }\end{array}$ & $\mathrm{PO}$ & $\begin{array}{c}\text { GAP } \\
\text { PO }\end{array}$ & $\begin{array}{c}\text { STD } \\
\text { HR }\end{array}$ & HR & $\begin{array}{c}\text { GAP } \\
\text { HR }\end{array}$ & $\begin{array}{c}\text { STD } \\
\text { OR }\end{array}$ & OR & $\begin{array}{l}\text { GAP } \\
\text { OR }\end{array}$ & $\begin{array}{l}\text { STD } \\
\text { CF }\end{array}$ & $\mathrm{CF}$ & $\begin{array}{c}\text { GAP } \\
\text { CF }\end{array}$ \\
\hline A & 2019 & May & 0.708 & 0.594 & -0.114 & 0.149 & 0.159 & 0.010 & 0.081 & 0.084 & 0.003 & 0.062 & 0.083 & 0.021 \\
\hline B & 2019 & November & 0.708 & 0.737 & 0.029 & 0.149 & 0.149 & -0.001 & 0.081 & 0.120 & 0.040 & 0.062 & 0.047 & -0.015 \\
\hline $\mathrm{C}$ & 2019 & June & 0.708 & 1.223 & 0.515 & 0.149 & 0.137 & -0.012 & 0.081 & 0.180 & 0.099 & 0.062 & 0.060 & -0.002 \\
\hline
\end{tabular}

According to Table 8, the PS gap values are either positive or negative in each criterion. The following is an explanation if the PS gap is negative:

- A negative GAP PO value means that PO has an Actual Value < Contract Value; potentially receiving PENALTY

- A negative GAP HR value means that HR has an Actual Value < Contract Value, GOOD condition (NO penalty)

- A negative GAP CF value means that CF has an Actual Value < Contract Value, WARNING condition (NO penalty) 
Meanwhile, the color on each gap performance score reflects:

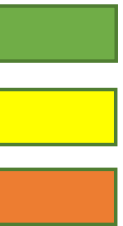

GOOD - Performance score meets or exceeds the contract value

WARNING - Performance score exceeds the contract value, but no impact on Penalty

BAD - Performance score is less than the contract value, potentially to get Penalty

Table 9 shows the gap analysis by comparing the three power plants.

Table 9. Gap Performance Score Between Power Plant

\begin{tabular}{cclll}
\hline $\begin{array}{c}\text { Power } \\
\text { Plant }\end{array}$ & Year & \multicolumn{1}{c}{ Month } & \multicolumn{1}{c}{ Remarks } & \multicolumn{1}{c}{ Caused By } \\
\hline A & 2019 & May & Penalty PO \& HR & $\begin{array}{l}\text { Actual PO = 25.18 MW; actual HR } \\
=9,861 \mathrm{Btu} / \mathrm{kWh}\end{array}$ \\
B & 2019 & November & No Penalty & \\
C & 2019 & June & No Penalty & \\
\hline
\end{tabular}

Table 9 shows that Power Plant A in May 2019 (PB) will receive a penalty for its PO and HR because the actual PO value $=25.18 \mathrm{MW}$, less than the contract $\mathrm{PO}$ value $=30 \mathrm{MW}$; and the actual $\mathrm{HR}$ value $=9,861 \mathrm{Btu} / \mathrm{kWh}$, which is higher than the contract HR value $=9,270 \mathrm{Btu} / \mathrm{kWh}$. Power Plant B in November 2019 (PB) will not receive a penalty. Power Plant C in May 2019 (PB) will not receive a penalty because its actual PO value and actual HR value are both less than the contract value.

\section{CONCLUSION AND RECOMMENDATIONS}

Electricity has become a basic requirement of every modern human being. The demand for electricity continues to increase over time. GEG power plants, as electricity producers, need to be maintained by monitoring performance, carrying out maintenance on time, and continuously making improvements.

In the balanced scorecard framework, performance measurement tools (PMTs) are a part of the learning and growth perspective - information capital section - planning, monitoring, reporting. For this reason, PMTs are essential to be defined and can help determine the performance of a power plant. Power plant companies are greatly helped by PMT when making decisions for continuous improvements.

The results of the analysis show that Power Plant A for its performance benchmarks (PBs) in May 2019 will be subjected to $\mathrm{PO}$ and HR penalties because the $\mathrm{PO}$ actual value $=25.18 \mathrm{MW}$ is less than the $\mathrm{PO}$ contract value $=30 \mathrm{MW}$ and the HR actual value $=9,861 \mathrm{Btu} / \mathrm{kWh}$ is higher than the HR contract value $=9,270 \mathrm{Btu} / \mathrm{kWh}$. The $2019 \mathrm{~PB}$ is the highest total performance score (TPS) in 2019, in which penalty takes place. This means, in other months of the year, it can be said that all penalties are a certainty. For Power Plant B in 2019, the performance benchmark in November is not subjected to a penalty. The same thing also applies to Power Plant C, as there were no penalties in 2019.

It can be said that if there is a gap in the performance score (PS), especially in PO and HR, there will be penalties from the customer. This penalty will have an impact on reducing the payments received from customers. This penalty can be identified by a negative value in the PO gap (meaning the PO actual value < PO contract value) and a positive value in the HR gap (meaning the HR actual value > HR contract value). Meanwhile, gaps in OR and CF do not have an impact on penalties.

By looking at these conditions, the management of the company must make improvements to reduce penalties. Improvement can be done by:

- Reducing PO penalties by increasing the availability and performance of gas engines at the power plant. Increasing availability can be done by performing preventive maintenance on schedule to minimize engine breakdown and to improve engine performance. If the availability and performance of the engine are optimized, the power plant can then produce adequate power output (MW) to achieve the PO contract requirement.

- Reducing HR penalties by lowering the HR of the gas engine at the power plant. The high HR can also be referred to as high fuel consumption. High fuel consumption on a gas engine requires the engine to be reset so that it consumes less fuel, i.e., reducing the heat rate of the gas engine. Therefore, the heat rate's actual value will not exceed the contract value. This engine resetting has been done by the company for a power plant in another location. This resetting serves to upgrade the engine version from Version $\mathrm{E}$ (the existing version) to Version $\mathbf{J}$ (the newer version). This engine version upgrade replaces some parts and performs resetting in the ECM engine. Based on the results that already exist, the HR will drop to $600-1000 \mathrm{Btu} / \mathrm{kWh}$. 
In addition, there are many things that the company can do when making decisions to ensure continuous improvements to the GEG power plants assisted by PMT. The energy business industry will continue to grow, thereby necessitating a management plan. Thus, power plant performance needs to be considered. The contribution of this study is that it overcomes the problem of a limited number of references that can be used to measure performance in the energy industry, especially GEG power plants.

For future research, the scope of studies that can be carried out are:

1. Performance indicators for maintenance can be considered in calculating the performance score of the power plants. This is because maintenance is crucial in reducing machinery breakdown by avoiding corrective maintenance at a high cost.

2. Performance Indicators for Health, Safety, Environment (HSE) can be considered in calculating the performance score of the power plants. The reason is that environmental issues, especially emissions, always lead to problems.

3. Performance Indicators for cost control can be considered in calculating the performance score of the power plants. Cost control is central to controlling the balance of production cost vs revenue.

4. The exploration of the influencing factors of KPI, especially for GEG power plants.

\section{REFERENCES}

Barzilai, J., \& Lootsma, F. A. (1997). Power relations and group aggregation in the multiplicative AHP and SMART. Journal of MultiCriteria Decision Analysis, 6(3), 155-165. https://doi.org/10.1002/(SICI)1099-1360(199705)6:3<155: AIDMCDA131>3.0.CO;2-4

Behn, R.D. (2003). Why Measure Performance? Different Purposes Require Different Measures. Public Administration Review, October 2003, Vol. 63, No. 5. Havard University.

Chalmeta, R., Palomero, S., \& Matilla, M. (2012). Methodology to develop a performance measurement system in small and mediumsized enterprises. International Journal of Computer Integrated Manufacturing, 25(8), 716-740. https://doi.org/10.1080/0951192X.2012.665178

Cheng, C., \& Qing-long, W. E. N. (2017). ScienceDirect containment cooling system Assessing the feasibility of using the heat demand-outdoor temperature function for a district heat demand forecast.

Clarke Energy, (2020). Independent Power Producers. https://www.clarke-energy.com/applications/independent-power-producers/

Colla, M., Ioannou, A., Falcone, G., Yilan, G., Kadirgan, M. A. N., Çiftçioğlu, G. A., Pramangioulis, D., Atsonios, K., Nikolopoulos, N. N., Rakopoulos, D., Grammelis, P., Kakaras, E. E., Oprea, S. V., Bâra, A., Kourkoumpas, D. S., Benekos, G., Nikolopoulos, N. N., Karellas, S., Grammelis, P., ... Tiurindah, V. V. (2011). Power Plant Life Management and Performance Improvement. Renewable and Sustainable Energy Reviews, 16 (2), 420-449. https://doi.org/10.1533/9780857093806.3.420

Colla, M., Ioannou, A., \& Falcone, G. (2020). Critical review of competitiveness indicators for energy projects. Renewable and Sustainable Energy Reviews, 125(March). https://doi.org/10.1016/j.rser.2020.109794

Deloitte Indonesia. (2016). 35,000 MW: A Light for the Nation. 1-50. https://www2.deloitte.com/content/dam/Deloitte/id/Documents/finance/id-fas-35000mw-a-light-for-the-nation-noexp.pdf

Energy education, (2020). Retrieved from Energy Education, University of Calgary. https://energyeducation.ca/encyclopedia/Power_plant

Energy Handle, (2020). Power Plants Operation and Maintenance. https://www.energyhandle.ma/power-plants-operation-andmaintenance/

Energypedia, (2020). Operation Model. https://energypedia.info/wiki/Operation_Models_(IPP,_BOT)_-_Wind_Energy

Fuentes-Pila, J., Garcia, J., Benito, S., Lopez-Cozar, C., Cedeno, P., Garcia, A., (2017). D2. 3 Electric Key Performance Indicators (KPIs) Prepared by: (n.d.). 1-124.

GE Jenbacher, (2013). Technical Description Genset JGS 620 GS-N.L.

GineersNow, (2020). How are Rental Power Plants Helpful? https://gineersnow.com/industries/electric-power/rental-power-plantshelpful

Hartono, J. (2015). Konsep dan Aplikasi Structural Equation Modeling (SEM) Berbasis Varian dalam Penelitian Bisnis. Public Administration Review, 63(5), 586-606.

Kanoğlu, M., Kazim Işik, S., \& Abuşoğlu, A. (2005). Performance characteristics of a Diesel engine power plant. Energy Conversion and Management, 46(11-12), 1692-1702. https://doi.org/10.1016/j.enconman.2004.10.005

Kaplan, R., and Norton, D., (1996). The Balanced Scorecard: Translating Strategy into Action. Boston, MA: Havard Business School Press.

Kamaruzzaman, S. N., Lou, E. C. W., Wong, P. F., Wood, R., \& Che-Ani, A. I. (2018). Developing weighting system for refurbishment building assessment scheme in Malaysia through analytic hierarchy process (AHP) approach. Energy Policy, 112 (October 2017), 280-290. https://doi.org/10.1016/j.enpol.2017.10.023

Kuragu, J.K.O, B.K. Baiden and E. Badu (2016), Performance measurement tools for Ghanaian contractors. International Journal of Construction Management, Vol. 16, No. 1, 13-26. http:// dx.doi.org/10.1080/15623599.2015.1115245

Maxpower Group, (2020). Official website Maxpower Group, a member of Medco Group. https://maxpowergroup.com/

Mehta B.R., and Reddy, Y.J. (2015). Industrial Process Automation Systems, Design and Implementation. Oxford, UK: Elsevier Inc.

Ministry of Energy and Mineral Resources. (2018). Performance Report of Directorate General of Electricity. 36-37. http://www.djk.esdm.go.id/pdf/LAKIP/LAKIN 2018.pdf

Morisawa, T. (2002). Building Performance Measurement Systems with the Balanced Scorecard Approach. Nomura Research Institute Ltd, 45(45), 47-52. http://www.china-gloves.com.cn/adminsthxh/upfiles/2007126942368570.pdf

Oprea, S. V., \& Bâra, A. (2017). Key Technical Performance Indicators for Power Plants. Recent Improvements of Power Plants Management and Technology. https://doi.org/10.5772/67858 
Power Magazine, (2020). Heat Rate Fundamentals. https://www.powermag.com/understanding-coal-power-plant-heat-rate-andefficiency/

Pramangioulis, D., Atsonios, K., Nikolopoulos, N., Rakopoulos, D., Grammelis, P., \& Kakaras, E. (2019). A methodology for determination and definition of key performance indicators for smart grids development in island energy systems. Energies, 12(2), 1-22. https://doi.org/10.3390/en12020242

Preston, V. (2020). Questionnaire Survey. In International Encyclopedia of Human Geography (Second Edi, Vol. 11). Elsevier. https://doi.org/10.1016/b978-0-08-102295-5.10860-1

Proces, H. (2010). Using the Analytic Hierarchy Process in Evaluating Decision Alternatives. Operations Research and Decisions, 20(1), 5-23.

PwC Indonesia. (2017). Power in Indonesia. November, 191. https://www.pwc.com/id/en/energy-utilities-mining/assets/power/powerguide-2017.pdf

Rasul, M. (2013). Thermal Power Plants - Advanced Applications, Edited by Mohammad Rasul. Rijeka, Croatia: Intech

Ruvania, F., Sofianti, T. D., \& Tertiana, D. I. (2015). Knowledge Management Evaluation in Oil and Gas Company Using Analytic Hierarchy Process. Performa, 14(1), 25-40.

Saaty, T. L. (1988). What is the analytic hierarchy process? NATO ASI Series, Vol. F48. Mathematical Models for Decision Support. Edited by G. Mitra. Springer Verlag Berlin Heidelberg.

Saaty, T. L., \& Kearns, K. P. (1985). The Analytic Hierarchy Process. Analytical Planning, 19-62. https://doi.org/10.1016/b978-0-08032599-6.50008-8

Saaty, R. W. (1987). The analytic hierarchy process-what it is and how it is used. Mathematical Modelling, 9(3-5), 161-176. https://doi.org/10.1016/0270-0255(87)90473-8

Salisbury, J. Kenneth (2016). Power-Plant Performance Monitoring.

Shaaban, M., Scheffran, J., Böhner, J., \& Elsobki, M. S. (2018). Sustainability assessment of electricity generation technologies in Egypt using multi-criteria decision analysis. Energies, 11(5). https://doi.org/10.3390/en11051117

Shopify, (2020). Benchmarking Definition. Business encyclopedia. https://www.shopify.co.id/encyclopedia/benchmarking

Kamaruzzaman, S. N., Lou, E. C. W., Wong P. F., Wood R. (2018). Developing weighting system for refurbishment building assessment scheme in Malaysia through Analytic Hierarchy Process (AHP) approach. Elsevier, Energy Policy 112 (2018) 280290. http://dx.doi.org/10/1016/j.enpol.2017.10.023

Tallapragada, P., Shkaratan, M., Izaguirre, A. K., Helleranta, J., Rahman, S., \& Bergman, S. (2009). Monitoring Performance of Electric Utilities: Indicators and Benchmarking in Sub-Saharan Africa. The World Bank, 262.

Vargas, L. G. (2011). Thomas L. Saaty. In International Series in Operations Research and Management Science (Vol. 147, pp. 577591). https://doi.org/10.1007/978-1-4419-6281-2_31

Widhiatmaka, Gunawan, Y., Simorangkir, C. L. F., \& Aman, M. (2017). Analisis Kinerja Pltu Indramayu Sepanjang Tahun 2015 Performance Analysis of Indramayu 'S Coal-Fired Power Plants in Year 2015. Ketenagalistrikan Dan Energi Terbarukan, 16(2), 97-106.

Williams, A. D. (2011). Power Plant Life Management and Performance Improvement. In Power Plant Life Management and Performance Improvement. https://doi.org/10.1533/9780857093806.3.420

Wongrassamee, S., Simmons, J. E. L., \& Gardiner, P. D. (2003). Performance measurement tools: The Balanced Scorecard and the EFQM Excellence Model. Measuring Business Excellence, 7(1), 14-29. https://doi.org/10.1108/13683040310466690

World Energy Council. (2016). Power Plant Performance: Efficiency \& Availability. 7.

Yang, Y., Li, B., \& Yao, R. (2010). A method of identifying and weighting indicators of energy efficiency assessment in Chinese residential buildings. Energy Policy, 38(12), 7687-7697. https://doi.org/10.1016/j.enpol.2010.08.018

\section{CONFLICT OF INTEREST}

No potential conflict of interest was reported by the authors. 


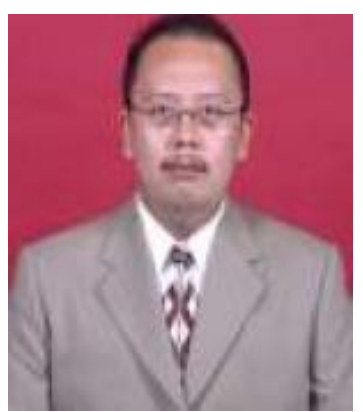

Dedi Emawan is a pursuing Master degree in Master of Mechanical Engineering, Swiss German University Indonesia.

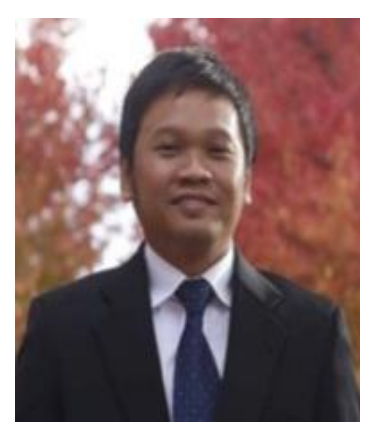

Dr. Eng. Aditya T. Pratama, S.Si., M.T. is a lecturer at Industrial Engineering, Swiss German University Indonesia. Email: aditya.pratama@sgu.ac.id. He handled several collaborative projects such as product development with industries, collaborative researches such as XML data exchange, online metering system, product life cycle management, ERP and collaborative working. His current research interests on collaborative working in manufacturing system, and production and operation management.

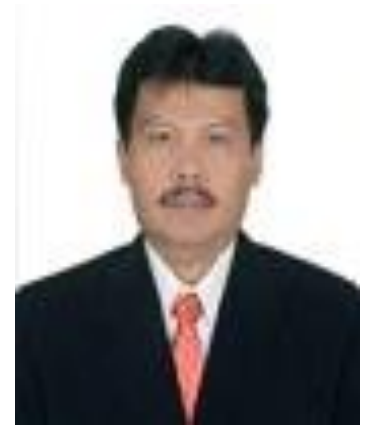

Dr. Ir. Henry Nasution, M.T. is a lecturer at Master of Mechanical Engineering, Swiss German University Indonesia. Email: henry.nasution@sgu.ac.id. He serves as the Member of Refrigeration and Air Conditioning Research Group (REFRAC), Automotive Development Centre (ADC) at Universiti Teknologi Malaysia, World Society of Sustainable Energy Technologies until now and Expert Panel of Malaysia Refrigeration and Air Conditioning Specialist (MRACS). Many of research projects he served as a leader did successful application in refrigeration and air conditioning system. 